
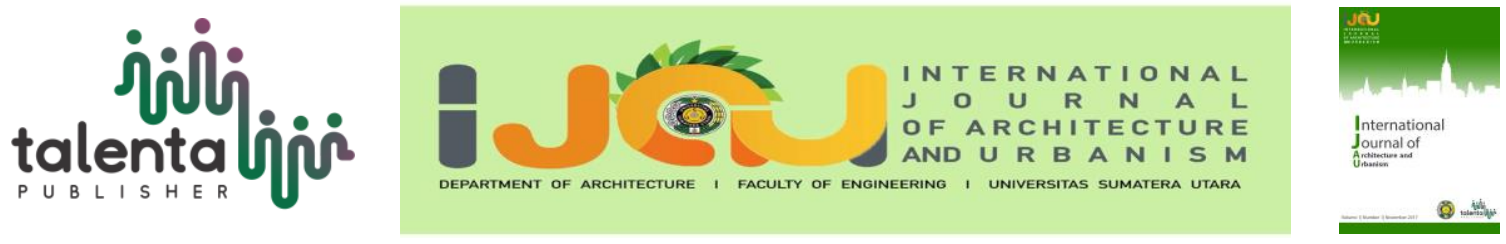

\title{
Integrated Kampong City Block in Kampong Bandur District of Medan Maimun
}

\author{
Dwira Nirfalini Aulia ${ }^{1 *}$, Nadiatul, Khairiah ${ }^{1}$ \\ ${ }^{1}$ Department of Architecture, Universitas Sumatera Utara, Medan, Indonesia
}

\begin{abstract}
Kampong Badur precisely is one of the slums in Medan City with the category of slum 'very bad' based on the Office of Housing and Settlements Medan 2015. Given the issues in various developing countries precisely in big cities in Indonesia are the increase in population and the process of urbanization. For that, the selection of strategies relating to the rearrangement by improving the old function and adding a new function is the strategy of Redevelopment. An urban redevelopment project that refers to the typical residential vernacular city of Indonesia called Kampong. So, in overcoming the problem of urban slum dwelling in low-income villagers who still put forward the typical residential vernacular Indonesia (kampong) is Kampong City Block. The concept of Kampong City Block is combined with the concept of economic improvement to overcome the problems of lowincome population slum area. In the case of Kampong Badur, social mapping in terms of livelihoods obtained some livelihoods that are considered to support the economic development of the population of trade, farming, chicken breeding, and small convection industry. The integration of these four sectors will be synergized in every design process. Then, the concept of Integrated Kampong City Block is also maintaining socio-culture of Badur people so that the approach to the theme of behavioral architecture and analysis of all aspects of the village community, ranging from the concept of macro and micro.
\end{abstract}

Keyword: slums, redevelopment, behavioral architecture, Kampong Badur

\section{Introduction}

Population growth is common in big cities such as Medan City which causes the proliferation of slum settlements in various places until it is uncontrolled as well. Slum settlements are unfit settlements due to building irregularity, high density, quality of buildings, and unqualified facilities and infrastructure (The Basic Law number 1 of article 56 of 2011 on Housing and Settlement Areas). The characteristics of slums include inadequate public facilities, inhabitants of socially and economically unsound slum settlements, the people have a livelihood, and a diverse level of density, settlements that have social coating based on the level of their different economies, and most residents work in the informal sector or have additional livelihoods in the informal sector [1].

*Corresponding author at:Department of Architecture, Faculty of Engineering, Universitas Sumatera Utara, Jalan Perpustakaan Gedung J07, Medan 20155, Indonesia

E-mail address: *dwira_aulia@yahoo.com 
Based on the theory of growth factors and the characteristics of slums mentioned and associated with the data of slum neighborhoods that exist in Medan City, Hamdan village precisely Kampong Badur district of Medan Maimun is one of the residential areas and slums with the category of slum 'very bad' [2]. Regarding the prevailing regulations, Kampong Badur in the absence of GSS, KDH, etc. Furthermore, the flood problem also inundated the Badur settlement due to the lack of Green Open Space (RTH), as well as the unavailability of a landfill (TPA) and government service which can not use the accessibility of the site to take the garbage at the settlement location due to insufficient road width. Then, the use of building materials that are not by the requirements of housing construction materials based on housing requirements according to the Head of Health Minister No.829 / Menkes / SK / VII / 1999.

Slum settlement arrangement of Medan City is a difficult task to be completed from time to time, where the socio-cultural conditions of people living in urban slums have been formed by adjusting their living areas. The handling of slum settlements by relocating these communities to unruly suburban (unproductive) areas will not be an effective way for governments to address these issues. The lives of people living in urban slums are already familiar with the proximity of the business center making relocation strategies often resent by local people. For this reason, a plan/strategy for rearrangement of a settlement area by improving existing old functions and adding new functions is Redevelopment. Currently, several urban redevelopment projects refer to the typical vernacular housing of Indonesian cities, commonly called Kampong. Based on the statements previously described, vertical housing is required that emphasizes the typical vernacular occupancy of Indonesia (Kampong) in the form of Kampong City Block [3], with strategies that can retain the physical and non-physical characteristics of occupants by replacing original residents without changing old social and lifestyle / cultural attitudes.

\section{Literature Review}

\subsection{Object Description}

The scope of the case in this project is low-income housing in densely populated urban areas. Based on the issue of slum settlement problems in the city of Medan one of them is located in the village Hamdan neighborhood 10 Kampong Badur. The assessment and design of this housing apply the right concept of vertical dwelling and contextual to the problems faced, especially the problem of the slums in the densely populated areas in general.

\subsection{Location and Site}

Based on the housing and settlement office of Medan City in 2015 concerning the determination of residential neighborhoods location and slum districts in 2015, Hamdan village districts of Medan Maimun have a 'very bad' slum rate ([2]. Based on the results of the literature survey, the selected location is Kampong Badur, which is located in neighborhood 10 of Hamdan Village, 
Medan Maimun District. Medan Maimun is a district located in the area of WPP D, which is the center of development in the core of the city. This area is built for commercial areas, offices, indoor recreation, and settlements, with programs of permanent housing construction, waste management and educational facilities based on RUTRK (General Plan of Urban Spatial Medan) 2016.

Geographically, Kampong Badur is located at $3^{\circ} 34^{\prime} 52$ "LU and $98^{\circ} 40^{\prime} 44^{\prime \prime}$ BT, which is located in the center of Medan. Regarding illustration related to Kampong Badur, the location is as follows on (Figure 1).

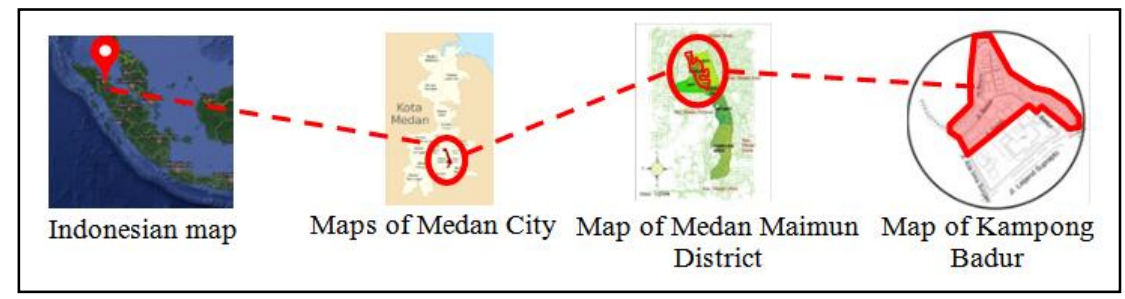

Figure 1. Map of Kampong Badur

(Source: Google Earth and Author 2017)

\subsection{Theme Review}

The idea of the project's basic theme is social-cultural with the improvement of the previous environmental quality by maintaining the behavioral characters of the villagers in a nonphysical and physical way that is expected to put the original residents back without changing the old social and lifestyle / cultural behavior. So that the deepening of the theme is realized with the use of architectural themes with insightful. Behavioral architecture can be interpreted as a built environment created by humans as a place to perform their activities by considering all aspects of the response or reaction of the human itself according to the mindset or perception of the human as the user. According to Amos Rapoport, in architectural design usually includes the organization of space, time, meaning, and color [4].

To determine a behavioral setting to be observed, it can take information files that categorized into: first, Human/user who is doing the activity and why doing the activity. Who controls behavior in the observation area. Second, the magnitude of the characteristics that explain how many people/hours are here, how much room is needed, how often and for how long the looping behavior occurs. Third, behavior objects like what types and how many behaviors occur, how possible the possibilities of stimulation, response, and adaptation. Fourth, activity patterns like what activities happen there, how unique and repetitive things users do.

As for the theme selection obtained from completion of low economic problems Kampung Badur people who tend to impact on the quality of facilities and infrastructure that support daily needs. It is hoped that improvements in socio-cultural aspects and potentials of prominent 
community habits can be used as an improvement in the economy, psychological, health, and important aspects in supporting the prosperity of the Badur people in the future.

\section{Methodology}

There are several methods carried out in the design project of Integrated Kampong City Block in Badur. Among them are location selection by collecting data by way of literature study, comparative study, field survey, social mapping, and also interview. Then, the concept approach with the method of analysis and synthesis. Finally, the final design approach which is the conclusion of the synthesis process to be translated into the design is the final design drawing.

In site selection, the project is linked to the main design issues of low-income settlements in urban dense residential areas, one of which is slum settlement with a literature review of Medan City structure. Several locations of settlements determined by PEMKO (City Government) Medan were then identified with literature references concerning the characteristics of slums. One of the relevant locations based on the literature review is Kampong Badur. Then, a field survey was conducted directly related to the incompatibility with the scope of the case studied using social mapping using the Rapid Appraisal methodology, i.e., conducting key informant interviews and direct observation. Then proceed to the concept approach through data analysis methods from the results of social mapping studies on the part of the needs of the region consisting of proposals of citizens and stakeholders. The results of the data are taken into account with the standards derived from the literature study for approaches to the concepts of planning and design.

The results of the analysis study were then synthesized by combining field data sources, literature, and empirical experiences studied in the analysis. The results are then processed into a concept of planning and design in the form of ideas and problem-solving strategies that form the basic idea / basic concept associated with the basic theme of the design. The merger of all concepts obtained is a form of the conclusion that is realized into a measurable work drawing in the form of drawing plans, appearance, the section of building, details, and design perspectives.

\section{Result and Discussion}

\subsection{Analysis of Behavioral Characteristics}

Based on the data obtained from social mapping, the analysis of Badur village community behavior will be grouped based on the criteria of the majority of the most dominant. The translation covers the majority of religion, work, social class, and age. The behavioral discussion will examine the activities, habits (tendencies of daily behavior), needs, and hobby.

In Kampong Badur, most of the people embraced Islam, so activities and needs that tend to dominate follow the pattern of Islamic religious society. The majority of the work in Kampong 
Badur residents has various types. Survey data on work in Kampong Badur are traders (48\%), cleaning employees in offices and hospitals (25\%), pedicab drivers (21\%), and less significant workers (6\%). This data was done to 25 respondents who live in Kampong Badur [5]. So from the data, the majority of dominant jobs are traders. The discussion on the work to be applied in economic development will be discussed in the analysis section of business group division based on the percentage of work that tends to the dominant economic improvement. The work applied is the trade, service providers (small industry convection), vertical plantation, and breeding (broiler). Most of the Badur people have low-income communities. The translation of the activities, habits, needs, and hobbies are more studied based on the system of activities of Badur people in outline. The population of Badur consists of 1037 inhabitants. Most of the people of Badur are older than 18 years old. Because adult data acquisition is not very specific about age, the review of the assessment

\subsection{Regional Potential Analysis}

There is four regional potential in Kampong Badur (trade, small industry convection, vertical plantation, and chicken farm). The types of trades that are occupied are street vendors, food stalls, and shops (snacks \& vegetables) (Figure 2). Regarding the types of food sold for street vendors are mostly Satay Padang which is typical of Padang cuisine from West Sumatra. This can be a potential for the economy of Badur people with typical Padang cuisine namely Satay Padang. Also, food stalls and hawker shops can be used as trading potential by applying the concept of commercial area strategy to the design.

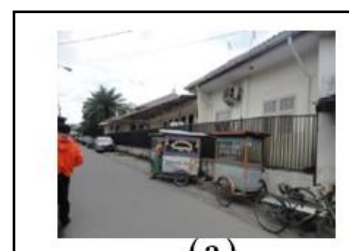

(a)

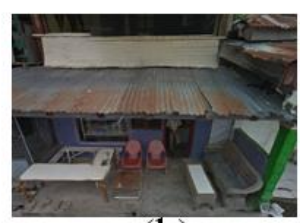

(b)

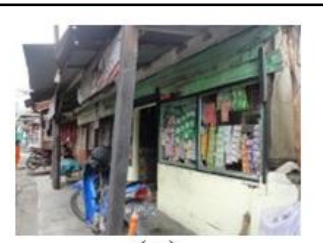

(c)

Figure 2. a. Street Vendors (PKL), b. Food Stall, c. Shops (Snack and vegetable)

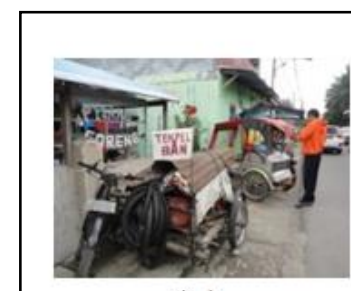

(a)

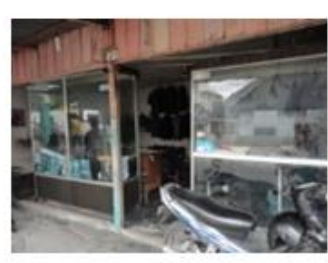

(b)

Figure 3. a. Pedicab drivers and tire repairers, b. Sewing services

Small industrial activities can't be separated from the activities of providing services. In Kampong Badur itself, there are small industries such as sewing service providers, transportation (Pedicab drivers), and tire services (Figure 3). Although the job of providing this 
service is only part / some of the citizens who pursue it, this profession can be transferred to the commercial area and also the diversion of the profession which further improve the economy of Kampong Badur people.

Some residents of Kampong Badur have a hobby of farming. This can be seen in the utilization of bamboo plants and also drink bottles as a medium for cultivating weighing the limitations of land in dense settlements (Figure 4). Utilization of this cultivated media is a unique and innovative idea. This can be potential as an improvement in the economy by making vertical plant area that can be utilized to plant various plants either from the type of vegetable/fruit that can be resold and the type of plant that can be processed as medicines. In Kampong Badur there are other activities that raise livestock that can be a potential Kampong Badur community. The type of livestock is chicken breeding. Some people use chicken breeding by selling eggs and also consumed for their own family (Figure 5).

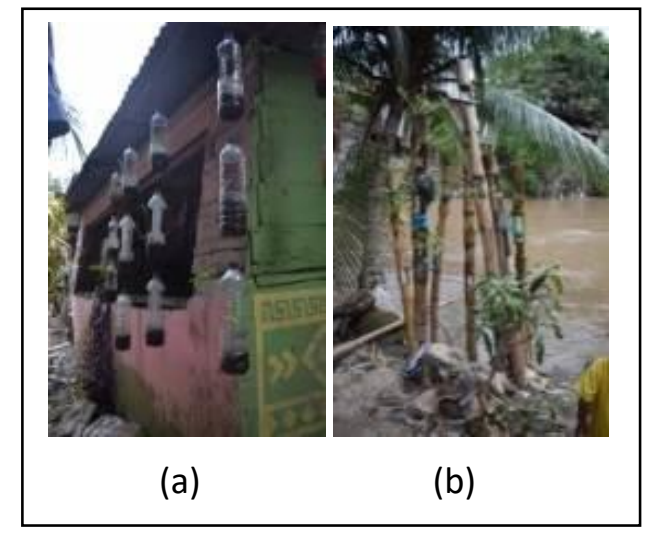

Figure 4. a. Vertikultur in bottle, b. Vertikultur in bamboo tree

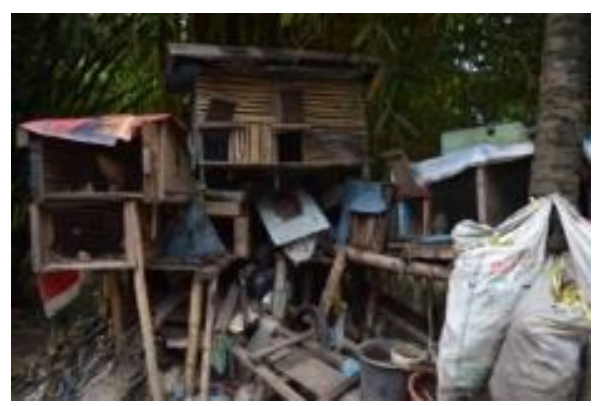

Figure 5. Chickens breeding activities of some residents

\subsection{Analysis of Regional Needs}

Based on the results of surveys and interviews with key sources of the head of the neighborhood, the Head of Silaturahmi Education Institution, and some residents who have been living in the kampong for a long time, there are several proposals in meeting the needs of Kampong Badur community. From the institutional side said that the people of Kampong Badur do not want to be relocated or moved from the settlement area. They want the Kampong Badur settlement to be reorganized but not by relocating. The inhabitants want improvement but 
cannot be separated from the pattern of life from the existing habits of society. Limited land and infrastructure facilities also become obstacles to the achievement of the welfare of Kampong Badur community. The distance between location and condition of the area also become one of obstacle factor.

Therefore, the proposed integrated residential pattern covering all aspects of the needs of residents by maintaining the pattern of occupancy, social, activities and habits/culture, and improving the quality of infrastructure facilities that become feedback in the economy of Kampong Badur. In the selection of the theme taken is still related to the positive behavior of the population, which often gather together in social activities, daily activities, and occupant's hobby.

\subsection{Analysis of Business Group Division}

The division of business groups in Integrated Kampung City Block is aimed for Badur community people who are categorized as the pre-prosperous society because their economic level is still low and can not support their daily life in the future. Therefore, the grouping is for 172 pre-prosperous families. The grouping of businesses categorized based on the potential analysis that has been done previously. The business potential consists of 4 groups: trade, small convection industry, vertical plantation, and chicken breeding. Analyzing the division of business groups is based on the percentage of the number of livelihoods occupied by Kampong Badur people. From the results of prior potential assessment analyzes, trade gained $48 \%$ percentage [5]. The business group division phase is obtained by using the dominant rating method based on technical, mechanical, male dominant workers, dominant female workers, and fastest profit earning (Tabel 1).

Table 1. Analysis of convenient business comparison assessment

\begin{tabular}{|c|c|c|c|c|}
\hline \multirow[b]{2}{*}{ NO } & \multirow[b]{2}{*}{$\begin{array}{l}\text { ASPECTS OF } \\
\text { CONVENIENT }\end{array}$} & \multicolumn{3}{|c|}{ Type of Business } \\
\hline & & $\begin{array}{c}\text { Chicken } \\
\text { Farm }\end{array}$ & $\begin{array}{c}\text { Vertical } \\
\text { Plantations }\end{array}$ & $\begin{array}{c}\text { Small } \\
\text { Convection } \\
\text { Industry }\end{array}$ \\
\hline 1 & Technical & 2 & 3 & 1 \\
\hline 2 & Mechanical & 1 & 3 & 2 \\
\hline 3 & $\begin{array}{l}\text { Male dominant } \\
\text { workers }\end{array}$ & 3 & 2 & 1 \\
\hline 4 & $\begin{array}{l}\text { Female dominant } \\
\text { workers }\end{array}$ & 1 & 2 & 3 \\
\hline 5 & $\begin{array}{l}\text { Fastest profit } \\
\text { earning }\end{array}$ & 3 & 2 & 1 \\
\hline & TOTAL POINTS & 10 & 12 & 8 \\
\hline
\end{tabular}


Table 2. Analysis of comparison percentage every business sectors

\begin{tabular}{lcccc}
\hline \multicolumn{1}{c}{ Business } & Trade & $\begin{array}{c}\text { Chicken } \\
\text { Farm }\end{array}$ & $\begin{array}{c}\text { Vertical } \\
\text { Plantations }\end{array}$ & $\begin{array}{c}\text { Small } \\
\text { Convection } \\
\text { Industry }\end{array}$ \\
\hline Percentage & $48 \%$ & & $52 \%$ & \\
Comparison & $\mathbf{8 2 ~ K K}$ & $\mathbf{3 0 ~ K K}$ & $\mathbf{4 5 ~ K K}$ & $\mathbf{1 5 ~ K K}$ \\
\hline Total KK & & & & \\
\hline
\end{tabular}

The analysis result shows the acquisition of the number of households in each business sector, where the trade is managed as many as $82 \mathrm{KK}$, chicken farm $30 \mathrm{KK}$, vertical plantations $45 \mathrm{KK}$, and small convection industry $15 \mathrm{KK}$ (Tabel 2).

\subsection{Space Program Analysis}

The division of communal spaces in residential dwellings is designed with the time-sharing system. Based on the analysis of social mapping, communal activities of Kampong Badur are divided into daily, weekly and monthly. For the daily communal space consists of children's play area $\&$ adults, Musholla, washing and drying area together, and commerce pocket space. Later, the weekly communal rooms are non-formal conference rooms and console warehouse equipment. And lastly, the monthly communal space is a multipurpose room.

In the division of the number of shelter units, calculations were analyzed based on population growth of Kampong Badur using Geometric Rate of Growth formula.

$$
\mathbf{P}_{\mathbf{t}}=\mathbf{P}_{\mathbf{0}}(\mathbf{1}+\mathbf{r}) \mathbf{t}
$$

Analyzes use two comparison of data from the population in Medan Maimun District based on data from Medan PEMKO (City Government), the total population in Medan Maimun in 2012 is 39,581 people, while in 201540,663 inhabitants.

So the result of population increase of Badur is 830 soul, so total population of 1867 soul. Based on the total number of Kampong Badur people currently numbering 1037 inhabitants with KK 221 , then on average, every family has five family members. With a 373 occupancy unit, it is estimated that the occupancy can accommodate the population according to the growth rate.

\subsection{Basic Concepts}

The elaboration of basic concepts that are applied based on the theme of behavior are adaptability, accessibility, comfortability, privacy, sociality, protected, and supervise. In building design projects, especially residential buildings should be able to accommodate any behavior that is done in Kampong Badur. Buildings should be able to accommodate the habit of social interaction that is often done by residents. Given the characteristic of kampong is the peculiarity of interaction space formed by the activity of socialization (pocket space), then 
designed a room that has high accessibility that is useful to accommodate the interaction between the gang. The design of the dwelling was built with ease of moving, both indoors and in an outdoor environment. The concept applied is a clear and open circulation pattern, clear signage, and can be reached from various directions.

Comfort is an important thing in this design, where the design will accommodate all the behavior and habits of each occupant. For that, communal space is available based on time units of daily, weekly, and monthly. Placem ents are located at various intersection points. The design of the room, especially in the occupancy, is designed privacy so that residents do not feel disturbed by other activities within the same building. But openings and spatial arrangements remain to be considered. The application of privacy applies to the concept of occupancy prosperous residing on the 2 nd floor. The use of typical kampung alleys is applied to residential corridors so that social interaction can still take place even though the occupancy has been built vertically. The occupants of the building have a desire in terms of security, protected from the surrounding environment, but without feeling constrained. Therefore, the direction of the building is a vegetation element that is used as a building block with the surrounding environment (Figure 6).

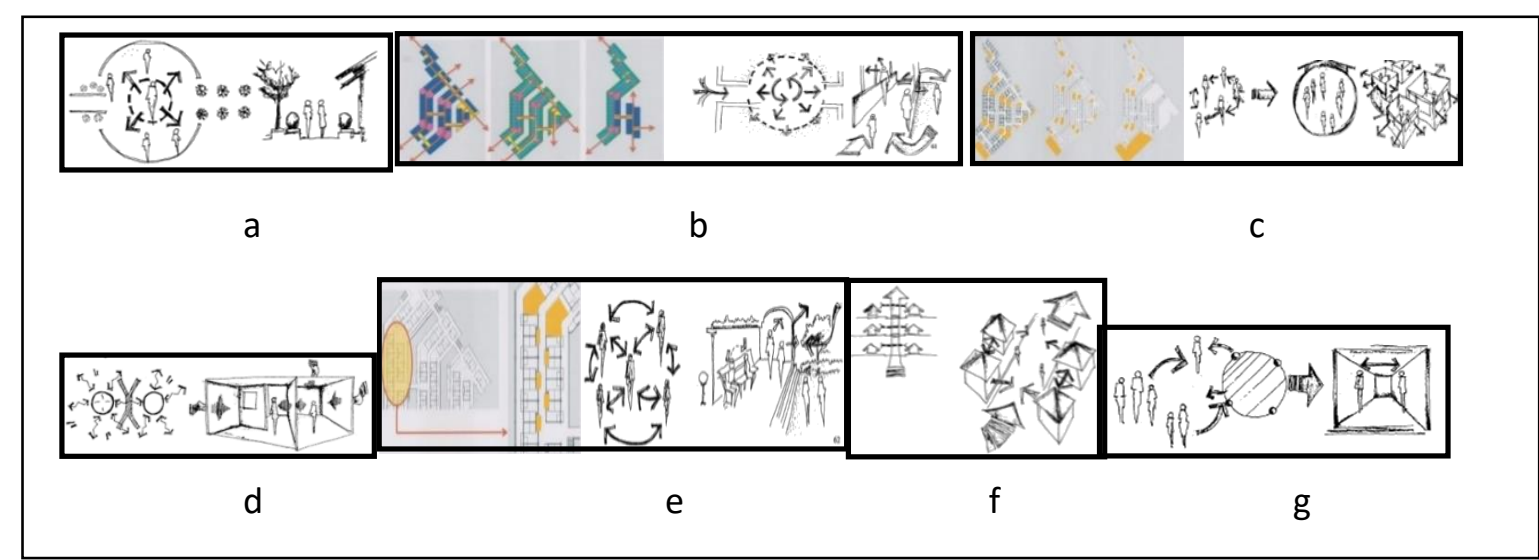

Figure 6. a. Adaptability, b. Accessibility, c. Comfortability, d. Privacy, e. Sociality, f. Protected, g. Supervise

(Source: Author and Arianti, Dwi. 2003)

Shelter occupancy and mass block will be used with the strategy of supervising the elements, considering the building occupants are not among adults, but also children. Therefore, the laying of each element of the building is designed to be easily visible and easily accessible.

\subsection{Spatial Concept}

The concept of vertical shelter is in the form of clusters adapted to the type of shelter based on the distribution of prosperous and pre-prosperous families, which is known the number of prosperous families 51 families and 171 Pre-prosperous families. So the division of type is medium and large (Figure 7). The number of units for prosperous KK that have been analyzed 
based on population increase of Badur village is 93 units with type 54m2 (A \& B), and Preprosperous 280 units with type $34 \mathrm{~m} 2$ (Figure 8 ).

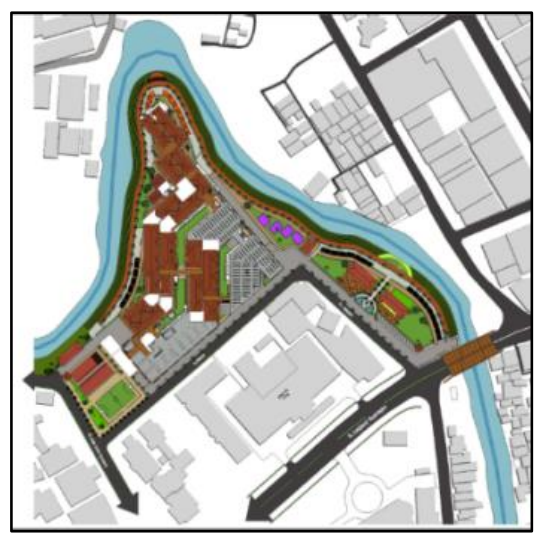

Figure 7. Site plan KCB

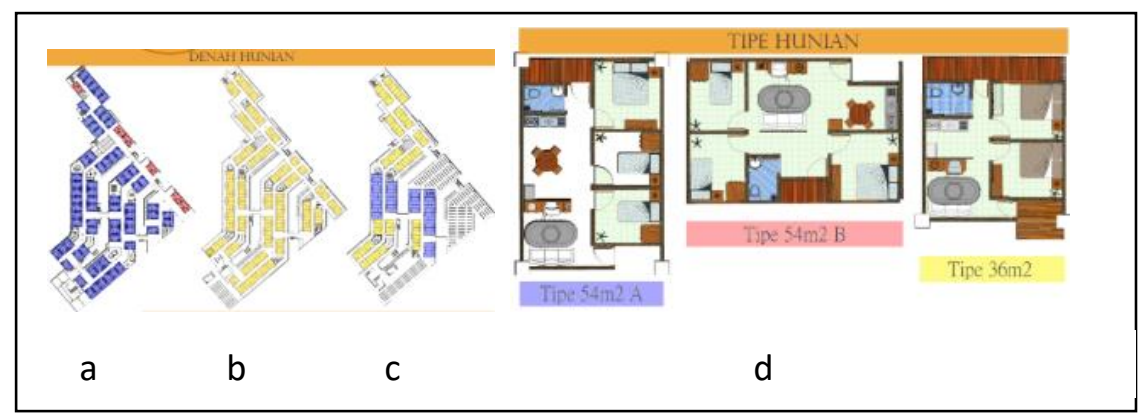

Figure 8. a. Floor plan (2), b. Floor plan (3.4,5), c. Floor plan (6), d. Type of residential hometown

The division of residential zones on the floor plan is intended for the concept of economic improvement that focuses on pre-prosperous society will be more optimal to the design needs of the villagers. The concept of residential spatial applies the flexibility of space in the form of elements of convertibility and versatility. Preparation of vertical cultivation land is applied with the Vertikultur system in vertical housing building. The application of Vertikultur system is used with two methods namely Hanging Vertikultur and Vertikultur Stacking.

Types of Generally Hanging Vertikultur seen in the form of pots or containers tied by rope/wire and hung on the roof. This system is applied to the Generally vertical section located on the rooftop of the residential area of the village. Stack Vertikultur systems are similar to Hanging Vertikultur, differing only in the use of containers and columns for the planting medium to be used. The application of stacking Vertikultur resides in each pre-prosperous shelter unit. The strategy of the division of Vertikultur territory is divided into two, namely General Vertikultur and Independent Vertikultur. Management of general Vertikultur managed by pre-prosperous KK who got part of planting sector with the amount of $45 \mathrm{KK}$. The land tenure system is divided according to the zone of plant species managed. For Independent Vertikultur, ownership of the system is divided into each unit of pre-prosperous KK with the number of 172 families. 
The ownership system is the distribution of Vertikultur stacking shelves of Paralon pipes with the number of 5 Paralon pipes with details of 3 racks / KK (units).

\subsection{The concept of mass and appearance}

For the concept of mass in settlements, the first concerning the handling of flood response methods based on the theory and technology described in research on flooded households. There are four handling, but the designer chooses the use of Wet Flood Proofing mass concept (Figure 10). For mass formation, the designer chooses the concept of single and double loaded, two lanes with void laying in the middle of occupancy (Figure 9). These two pathways allow interaction between citizens and the application of the pocket space in each corridor, so the concept of integrated in 4 sectors can be implemented with efficient (Figure 11).

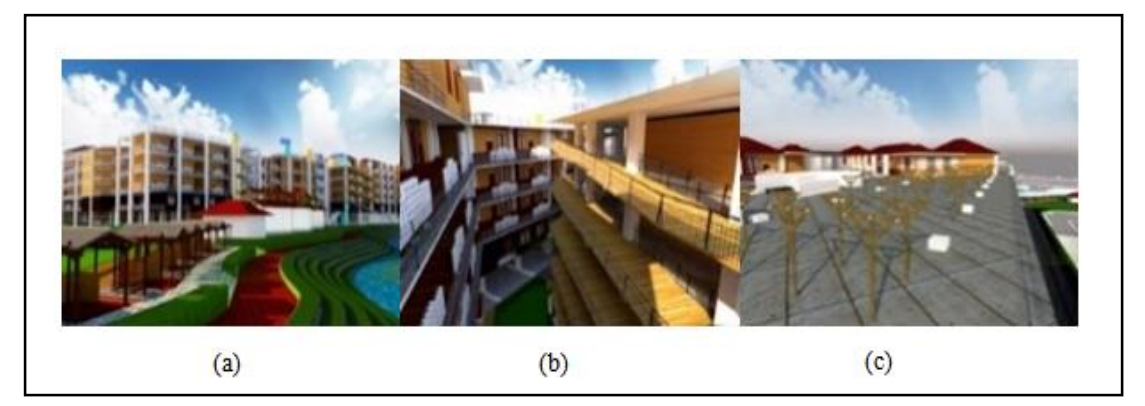

Figure 9. a. The atmosphere of jogging track and bicycle ways, b. View between blocks of dwelling from ramp kampong, $c$. The atmosphere of general drying area

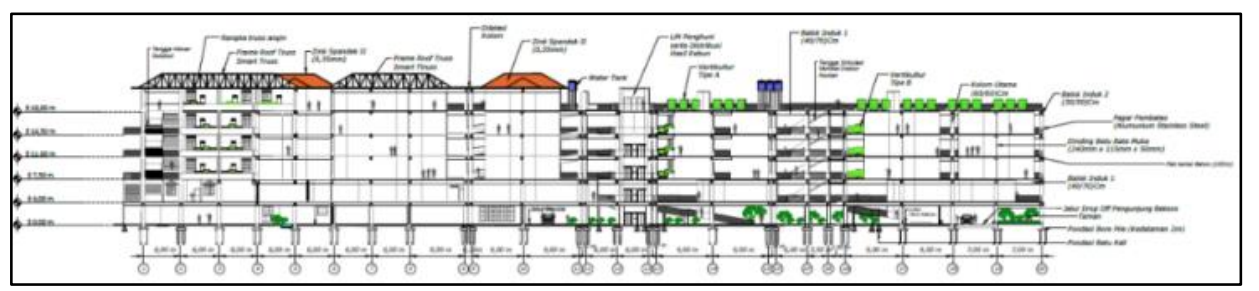

Figure 10. Section of kampong building
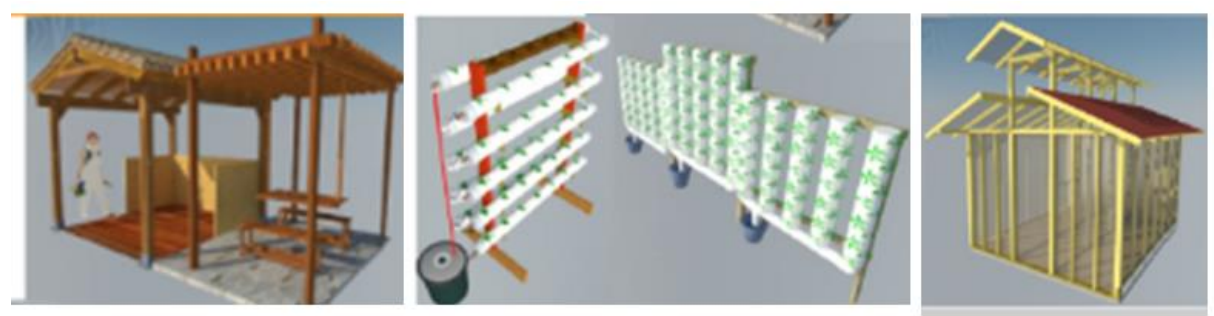

Figure 11. Integrated system strategy on improving the economy of kampong

\section{Conclusion}

Integrated Kampong City Block here is intended to be the urban village with vertical residential development by maintaining the socio-culture of Badur people, potential livelihoods, and the hobbies of residents through the theme of behavioral architecture approach. The educational 
system is re-applied from social activities along with the interaction arising from the pattern of the residential alley that already existed. The addition of commercial facilities as a distribution of trade and services as well as facilities of farming and poultry (broiler) independently vertically on the concept of occupancy with limited land that is the economic improvement strategy of residents in the future. The rest of the land is used for public facilities of Medan City with green open space as a flood prevention catchment area which is presented with a row of commercial centers that adorn the waterfront of Deli river.

\section{Acknowledgment}

This research is part of the requirement to obtain a bachelor's degree in Architecture Department, Universitas Sumatera Utara.

\section{REFERENCES}

[1] P. Suparlan. Segi Sosial Dan Ekonomi Pemukiman Kumuh. Buletin Antropologi. 4: 27-31, 1990.

[2] D. S. Lubis. Strategi Pembangunan Perumahan dan Permukiman untuk Mengatasi Masalah Permukiman Kumuh di Kota Medan. USU Digital library. 2016.

[3] A. N. A. Putri and W. Setyawan. Redevelopment Permukiman Informal untuk Peningkatan Kualitas Lingkungan Sosial. Jurnal Sains dan Seni ITS, 2016, 5.2.

[4] H. B. Setiawan. Arsitektur dan Perilaku Manusia. PPLH Universitas Gadjah Mada, Jogyakarta. 1996.

[5] M. Harahap. Struktur Permukiman di Kampung Badur. USU Digital library. 2016. 